\title{
PROBLEM POSING: UPAYA MENINGKATKAN KEMAMPUAN KOMUNIKASI DAN PRESTASI BELAJAR FISIKA SISWA
}

\author{
Sutijo1, Ika Rahmania1, Hestiningtyas Yuli P.2, Dwi Haryoto1 \\ 1Jurusan Fisika, FMIPA, Universitas Negeri Malang, Jl. Semarang No. 5 Malang \\ 2Prodi Pendidikan Fisika, FST, Universitas Kanjuruhan Malang, Jl. S. Supriadi Malang \\ e-mail: sujito.fmipa@um.ac.id
}

\begin{abstract}
ABSTRAK
Siswa di salah satu Madrasah Aliyah Negeri (MAN) Kota Malang memiliki daya nalar, inovasi, dan kemampuan komunikasi yang rendah. Hal ini ditunjukkan oleh sebagian besar siswa tidak mampu mencapai nilai SKM dan tidak memperhatikan saat teman melakukan presentasi. Berdasarkan observasi, siswa yang tidak mencapai nilai SKM adalah $68 \%$. Solusi yang diterapkan untuk memecahkan masalah ini adalah menerapkan pembelajaran dengan pendekatan problem posing. Proses pembelajaran ini diharapkan mampu meningkatkan kemampuan komunikasi dan prestasi belajar siswa. Pembelajaran yang diterapkan adalah Penelitian Tindakan Kelas (PTK). Data dikumpulkan melalui observasi dan hasil tes formatif pada setiap akhir siklus. Keterlaksanaan pendekatan problem posing mengalami peningkatan dari siklus I sebesar $80 \%$ menjadi $90 \%$ pada siklus II. Kemampuan komunikasi siswa juga mengalami peningkatan sebesar 67,6\% pada siklus I dengan kriteria cukup, siklus II 75\% dengan kriteria baik. Sementara untuk prestasi belajarpun mengalami peningkatan, pada siklus I rata-ratanya sebesar 69,7 dan pada siklus II rata-ratanya menjadi 85,7.
\end{abstract}

Kata kunci: problem posing, kemampuan komunikasi, prestasi belajar

\begin{abstract}
Students in one of State Madrasah-Aliyah of (MAN) the Malang City have low reasoning power, innovation, and communication skills due to lack of concentration. Based on observations, students who did not achieve SKM scores were 78\%. Solution applied to solve this problem is to apply learning with approach of problem posing. This learning process is expected to be able to improve communication skills and student achievement. The applied learning is Classroom Action Research (CAR). Data was collected through observation and formative test results. Implementation of the problem posing approach has increased from cycle I by $80 \%$ to $90 \%$ in cycle II. Communication skills of students also increased, which in the first cycle was 67.6\% with sufficient criteria, increased in the second cycle to $75 \%$ with good criteria. While learning achievement also increased, in the first cycle the average was 69.7 and in the second cycle the average rose to 85.7 .
\end{abstract}

Keywords: problem posing, communication skills, learning achievement

DOI: http://dx.doi.org/10.15575/jotalp.v5i1.65692

Received: 14 Agustus 2019; Accepted: 2 Januari 2020 ; Published: 29 Februari 2020 


\section{PENDAHULUAN}

Berdasarkan hasil wawancara dengan guru bidang studi Fisika kelas X diperoleh informasi bahwa selama ini pada umumnya proses pembelajaran fisika di salah satu Madrasah Aliyah Negeri (MAN) Kota Malang menggunakan metode ceramah, diskusi, demonstrasi, dan LKS. Diskusi yang biasa diterapkan selama ini dengan cara presentasi kelas oleh salah satu kelompok siswa, untuk kelompok lain, seharusnya memperhatikan dan menanggapi presentasi yang dilakukan atau menanyakan mengenai hal yang berkaitan dengan materi yang belum dipahami. Namun, pada kenyataannya kelompok yang lain ngobrol sendiri dan kurang memperhatikan presentasi, sehingga informasi yang didapatkan tidak maksimal. Hal ini dapat terjadi karena kemampuan komunikasi siswa yang kurang, sehingga dalam menyampaikan informasi hasil diskusi kepada teman kurang jelas.

Berdasarkan hasil pengamatan awal yang dilakukan di salah satu MAN kelas X-A menunjukkan bahwa kegiatan pembelajaran masih menggunakan metode ceramah, dimana guru berperan lebih dominan daripada siswa. Guru aktif menjelaskan di depan kelas dan memberikan penugasan kepada siswa. Siswa lebih banyak pasif, bahkan tidak jarang siswa bosan untuk mengikuti proses pembelajaran yang terlihat dari banyaknya siswa yang mengantuk pada saat guru menjelaskan materi. Hal ini mengakibatkan siswa mengalami kesulitan dalam memahami materi fisika yang akhirnya berdampak pada nilai ulangan harian yang mereka peroleh. Berdasarkan hasil observasi yang dilakukan, $12 \%$ siswa belum memperoleh nilai sesuai SKM yang telah ditentukan oleh sekolah yaitu sebesar 7,5. Mereka baru memperoleh nilai di atas SKM setelah diadakan remidi.

Selain hasil observasi awal, hasil wawancara dengan guru Fisika juga menunjukkan bahwa siswa kurang memiliki kemampuan berkomunikasi. Komunikasi pembelajaran antara siswa dengan guru jarang dilaksanakan. Siswa yang mengalami kesulitan belajar hanya berdiam diri. Siswa tidak berani mengajukan pertanyaan untuk menjawab kesulitan yang mereka alami. Siswa juga tidak berani menjawab pertanyaan yang diajukan oleh guru. Kondisi seperti ini membuat guru sulit memprediksi pemahaman siswa.

Masalah yang dihadapi oleh siswa mendorong perlunya penerapan suatu pendekatan pembelajaran yang mampu melatih dan menumbuhkan kemampuan komunikasi dan prestasi belajar siswa. Pendekatan pembelajaran yang saat ini banyak dikembangkan adalah pembelajaran berbasis konstruktivisme. Salah satu bentuk pembelajaran berbasis konstruktivisme adalah pembelajaran dengan pendekatan Problem Posing. Problem posing dilakukan siswa dengan cara merumuskan atau membentuk soal dari suatu situasi yang sudah tersedia. Merumuskan soal merupakan suatu aktivitas dalam pembelajaran yang dapat mengembangkan motivasi dan kemampuan siswa (Otero, Pollock, and Finkelstein 2010). Dalam pembelajaran dengan menggunakan pendekatan problem posing, siswa dapat memperoleh pengetahuan secara langsung dalam merumuskan soalnya sendiri (Ismayani 2016). Selain itu, pada proses pembelajaran dengan pendekatan problem posing ini ada tahapan dimana siswa berdiskusi dengan kelompoknya, selain itu juga ada kegiatan diskusi kelas. Jadi dengan adanya proses diskusi ini diharapkan dapat meningkatkan kemampuan komunikasi siswa.

Hasil penelitian para ahli pendidikan menemukan bahwa pembelajaran dengan problem posing lebih berdampak positif terhadap hasil belajar siswa. Menurut penelitian (Azhar 2001) katakan bahwa pendekatan prolem possing lebih efektif dalam meningkatkan prestasi belajar siswa daripada pembelajaran konvensional. Oleh karena itu, penelitian ini mengambil tema implementasi pembelajaran dengan menggunakan pendekatan Problem Posing untuk meningkatkan kemampuan komunikasi dan 
prestasi belajar fisika siswa (Enden, Chaerul, and Yuningsih 2016).

Pendekatan problem posing merupakan pendekatan pengajaran yang berbasis kontruktivisme yang dikembangkan oleh Paulo Freire dengan tujuan untuk memperkaya proses pengajaran dan juga merupakan cara baru bagi guru dalam menjalankan perannya sebagai fasilitator pembelajaran (Martin 1989).

Problem posing merupakan suatu pendekatan dalam proses pembelajaran yang membangun struktur kognitif siswa serta dapat memotivasi siswa untuk lebih berfikir kritis dan kreatif, karena dalam pembelajaran dengan pendekatan problem posing ini siswa mendapatkan pengalaman langsung dalam merumuskan (membentuk) soalnya sendiri (Barak 2017; Feinstein and Kirchgasler 2015). Kegiatan pada saat merumuskan atau membentuk soal akan memberikan suatu kesempatan kepada siswa untuk dapat menuangkan pikiran-pikirannya dan kegiatan pembelajaran ini akan bermakna sesuai dengan kemampuan yang dimiliki siswa. Pada pendekatan problem posing ini siswa akan diberi kesempatan untuk berkreasi dalam merumuskan persoalan dan akan lebih mendorong siswa untuk dapat bertanggung jawab dalam sistem pembelajaran (Care, Griffin, and Wilson 2018).

Menurut Zubair, komunikasi merupakan suatu proses pembentukan, penyampaian, penerimaan dan pengolahan pesan yang terjadi di dalam diri seseorang dan atau di antara dua atau lebih dengan tujuan tertentu. Dalam interaksi belajar mengajar baik guru maupun siswa lebih dominan menggunakan komunikasi secara lisan dan komunikasi secara tertulis. Untuk itu diperlukan adanya komunikasi yang efektif (Martuti and Diantoro 2013).
Menurut Nasution, untuk memperluas komunikasi siswa dapat dijalankan berbagai usaha. Salah satu usaha yang dapat dilakukan adalah dengan belajar kelompok (Alshamali and Daher 2016). Dengan belajar kelompok, kemampuan komunikasi siswa diharapkan bisa lebih baik. Kemampuan komunikasi yang dimaksud adalah kemampuan individu untuk menyampaikan pikiran dan perasaan, kemampuan memahami orang lain, kemampuan memberikan dukungan serta kemampuan mengungkapkan diri pada orang lain pada saat diskusi kelompok.

Menurut Dimyati dan Mujiono, prestasi belajar merupakan hasil dari interaksi tindak belajar dan tindak mengajar (Bollen et al. 2016). Dari sisi guru, tindak mengajar diakhiri oleh evaluasi prestasi belajar dan dari sisi siswa prestasi belajar merupakan puncak proses belajar. Berdasarkan taksonomi, tujuan pendidikan yang dikembangkan oleh Benjamin S. Bloom meliputi kognitif, afektif dan psikomotorik. Namun, untuk prestasi belajar hanya difokuskan pada ranah kognitif saja.

\section{METODE PENELITIAN}

Jenis penelitian ini adalah penelitian tindakan kelas. Penelitian tindakan kelas untuk tiap siklusnya terdiri dari 4 fase, yaitu rencana (planning), tindakan (action), pengamatan (observation) dan refleksi (reflection) (N.S. Rajendran 2002). Tindakan yang akan dilakukan oleh peneliti adalah penerapan pendekatan problem posing. Penelitian ini bertujuan untuk meningkatkan kemampuan komunikasi dan prestasi belajar siswa. Dalam penelitian ini, peneliti bertindak sebagai perencana tindakan, pengumpul data, penganalisis dan pelapor hasil penelitian. Peneliti dibantu oleh teman sejawat yang bertindak sebagai observer, sedangkan guru kelas berperan sebagai pelaksana kegiatan pembelajaran problem posing. 
Subjek penelitian ini adalah siswa kelas X-A semester II tahun ajaran 2008/2009. Kelas X-A merupakan kelas bayangan IPA dengan jumlah siswa 36 orang. Data yang diambil dalam penelitian ini meliputi data keterlaksanaan proses pembelajaran problem posing, data kemampuan komunikasi siswa dan prestasi belajar siswa. Data tentang proses pembelajaran problem posing, prestasi belajar siswa aspek kognitif, serta kemampuan komunikasi siswa diperoleh dari hasil observasi.

Penelitian ini, untuk mengumpulkan data digunakan instrumen. Instrumen penelitian yang digunakan adalah perangkat pembelajaran yang berupa berupa RPP, LKS dan lembar problem posing, lembar observasi yang digunakan yaitu lembar observasi keterlaksanaan proses pembelajaran dengan pendekatan problem posing dan lembar observasi kemampuan komunikasi siswa, soal tes digunakan untuk mengukur prestasi belajar kognitif siswa. Pemberian tes dilakukan pada akhir siklus I dan siklus II.

Data yang telah diperoleh akan dianalisis melalui penyederhanaan data, dan menelaah semua data yang diperoleh dari kegiatan observasi dan tes. Data mengenai keterlaksanaan proses pembelajaran problem posing diperoleh berdasarkan hasil observasi untuk setiap indikator yang dilakukan oleh guru dan siswa selama proses kegiatan pembelajaran berlangsung untuk setiap siklusnya. Selanjutnya dipaparkan pada paparan data tentang pelaksanaan pembelajaran setiap siklusnya. Untuk data kuantitatif, hasil observasi setiap indikator baik guru maupun siswa setiap siklusnya diubah dalam bentuk persentase. Persentase dapat dihitung dengan rumus sebagai berikut.

$$
\% \text { Keberhasilan }=\frac{\sum \text { skor tercapai }}{\sum \text { skor } \text { maksimum }} \times 100 \%
$$

(Creswell 2009)
Data mengenai kemampuan komunikasi siwa diperoleh berdasarkan hasil observasi untuk setiap indikator yang dilakukan pada setiap siswa selama proses kegiatan pembelajaran berlangsung untuk setiap siklusnya. Selanjutnya mengubah dalam bentuk persentase. Persentase dapat dihitung dengan rumus sebagai berikut.

$$
\% \text { Keberhasilan }=\frac{\sum \text { skor tercapai }}{\sum \text { skor maksimum }} \times 100 \%
$$

(Creswell 2009)

\section{HASIL DAN PEMBAHASAN}

\section{Observasi Awal}

Wawancara dengan guru bidang studi Fisika kelas X diperoleh informasi bahwa proses pembelajaran fisika khususnya kelas X-A menggunakan metode ceramah, diskusi, dan LKS. Diskusi yang biasa diterapkan selama ini dengan cara presentasi kelas oleh salah satu kelompok siswa, untuk kelompok lain memperhatikan dan menanggapi presentasi yang dilakukan atau menanyakan mengenai hal-hal yang berkaitan dengan materi yang belum dipahami. Namun, pada kenyataannya kelompok yang belum presentasi hanya ngobrol sendiri, tidak memperhatikan presentasi sehingga informasi yang didapatkan tidak maksimal.

Selain itu, prestasi belajar siswa rendah, dimana pada saat observasi dilakukan ditemukan bahwa pada saat dilakukan tes formatif, banyak anak yang nilainya di bawah SKM yang telah ditetapkan. Dari 36 siswa hanya 5 siswa yang tuntas dalam tes formatif, sementara siswa lainnya tidak tuntas dalam belajar. Hal ini mengindikasikan bahwa kelas X-A merupakan kelas dengan ranking paling rendah di antara kelas X lainnya. Siswa cenderung pasif dalam pembelajaran. Ini mengindikasikan kemampuan komunikasi siswa dalam diskusi kelas kurang.

Untuk itu, terdapat sebuah penelitian tindakan kelas atau PTK yang menurut Suharjdono merupakan sebuah tidakan yang dilakukan supaya 
dapat memperbaiki atau meningkatkan kualitas proses pembelajaran di dalam kelas (Asrori, 2008, p. 4). Penelitian tindakan kelas ini menurut Prof. Dr.H. Mohammad Asrori M.Pd. terdiri dari empat langkah, yakni pertama perencanaan atau planning yang di dalamnya terdapat kegiatan untuk menyusun rencana tindakan yang mengandung unsur $5 \mathrm{~W}+1 \mathrm{H}$; yang kedua tindakan atau action yang merupakan pelaksaanaan dari perencanaan yang telah disusun ; yang ketiga obervasi atau observation yang dilaksanakan bersamaan dengan kegiatan tindakan; dan yang terakhir refleksi atau reflection yang merupakan tindakan analisis keseluruhan kegiatan yang telah dilaksanakan berdasarkan data yang telah di dapatkan (Asrori, 2008, pp. 100-105).

Pada penelitian tindakan kelas, terdapat langkah observasi yang dalam peelitian ini dilakukan kegiatan observasi langsung di kelas dengan proses pembelajaran masih cenderung bersifat informasi dari guru ke siswa. Siswa malu-malu dalam mengungkapkan pendapat mereka. Siswa juga kurang bisa berbagi informasi dengan temannya tentang materi pelajaran. Sikap saling menghargai antar sesama siswa juga masih kurang. Hal ini terlihat pada saat temannya maju ke depan mengerjakan soal, siswa yang lain banyak yang ngobrol dengan temannya, tidak mau memperhatikan teman yang memberi penjelasan di depan.

\section{Siklus Pertama}

Hasil analisis pelaksanaan siklus pertama diuraikan sebagai berikut:

a. Keterlaksanaan pendekatan problem posing pada siklus pertama berjalan kurang, sebab pada saat tahapan problem posing yaitu tahap mendeskripsikan situasi/informasi, kegiatan yang dilakukan oleh guru masih kurang, dimana guru hanya memberikan penjelasan tentang materi tanpa diadakan demonstrasi maupun praktikum. Sehingga pada siklus I diperoleh persentase keterlaksanaan pembelajaran problem posing sebesar $80 \%$.

b. Masih ada beberapa siswa yang bersikap acuh dan tidak mau membantu temannya yang lain yang belum mengerti dan memahami pertanyaan dan jawaban yang telah dikerjakannya. Siswa juga masih malu-malu mengkomunikasikan pendapat mereka baik pada saat diskusi kelompok maupun presentasi sehingga diperoleh rata-rata persentase kemampuan komunikasi siswa sebesar 67,6\%. Persentase kemampuan komunikasi siswa untuk setiap aspeknya dapat dilihat pada Tabel 1 berikut ini.

Tabel 1. Persentase Kemampuan Komunikasi Siswa untuk Setiap Aspeknya

\begin{tabular}{|c|c|c|}
\hline Aspek yang diukur & Persentase & Kualitas \\
\hline $\begin{array}{l}\text { Kemampuan } \\
\text { menyampaikan pikiran } \\
\text { dan perasaan }\end{array}$ & $78,7 \%$ & Baik \\
\hline $\begin{array}{l}\text { Kemampuan memahami } \\
\text { orang lain }\end{array}$ & $66,7 \%$ & Cukup \\
\hline $\begin{array}{l}\text { Kemampuan memberi } \\
\text { dukungan }\end{array}$ & $46,3 \%$ & $\begin{array}{l}\text { Sangat } \\
\text { kurang }\end{array}$ \\
\hline $\begin{array}{l}\text { Kemampuan } \\
\text { mengungkapkan diri }\end{array}$ & $78,7 \%$ & Baik \\
\hline
\end{tabular}

c. Data prestasi belajar yang diperoleh siswa pada siklus I masih kurang, sebab masih didapati banyak siswa yang belum tuntas dalam pembelajaran. Data prestasi belajar siswa siklus I, dapat dilihat pada Tabel 2 berikut ini:

Tabel 2. Data Prestasi Belajar Siswa Siklus I

\begin{tabular}{cccc}
\hline $\begin{array}{c}\text { Jumlah } \\
\text { siswa } \\
\text { yang } \\
\text { tuntas } \\
\text { belajar }\end{array}$ & $\begin{array}{c}\text { Jumlah } \\
\text { siswa } \\
\text { yang } \\
\text { tidak } \\
\text { tuntas } \\
\text { belajar }\end{array}$ & $\begin{array}{c}\text { Persentase } \\
\text { ketuntasan } \\
\text { klasikal }\end{array}$ & $\begin{array}{c}\text { Rata-rata } \\
\text { hasil tes } \\
\text { formatif }\end{array}$ \\
\hline 13 & 23 & $36,1 \%$ & 69,7 \\
\hline
\end{tabular}

\section{Siklus Pertama}

Hasil analisis pelaksanaan siklus kedua diuraikan sebagai berikut:

a. Keterlaksanaan pendekatan problem posing pada siklus kedua berjalan lebih baik daripada keterlaksanaan pendekatan problem posing pada siklus pertama. 
b. Pada saat kerja berkelompok sudah ada interaksi secara langsung antar anggota kelompok. Siswa sudah mau saling bekerjasama dan berbagi informasi tentang sub pokok bahasan yang dipelajari dengan teman satu kelompoknya. Siswa sudah bisa menghargai bila ada teman yang sedang menyampaikan pendapat, malah sering menanggapi pendapat temannya tersebut pada saat diskusi kelompok. Pada saat presentasi hasil diskusi kelompok, siswa sudah tidak malu dan tidak ragu-ragu lagi untuk maju ke depan mempresentasikan hasil diskusi kelompoknya. Sebagian kelompok masih ada yang hanya menguasai materi yang dipresentasikan dan materi yang mereka diskusikan. Pada saat diskusi kelas, siswa sudah berani mengajukan pendapat. Sehingga rata-rata persentase kemampuan komunikasi siswa untuk siklus II selama tahapan problem posing adalah sebesar $75 \%$, dan ini dikatakan sudah baik. Untuk data persentase kemampuan komunikasi siswa pada siklus II untuk setiap aspeknya ada pada Tabel 3 berikut ini:

Tabel 3. Persentase Kemampuan Komunikasi Siswa Untuk Tiap Aspeknya

\begin{tabular}{lcc}
\hline \multicolumn{1}{c}{ Aspek yang diukur } & Persentase & Kualitas \\
\hline $\begin{array}{l}\text { Kemampuan } \\
\text { menyampaikan pikiran } \\
\text { dan perasaan }\end{array}$ & $75,9 \%$ & Baik \\
$\begin{array}{l}\text { Kemampuan } \\
\text { memahami orang lain }\end{array}$ & $78,7 \%$ & Baik \\
$\begin{array}{l}\text { Kemampuan memberi } \\
\text { dukungan }\end{array}$ & $69,4 \%$ & Cukup \\
$\begin{array}{l}\text { Kemampuan } \\
\text { mengungkapkan diri }\end{array}$ & $75,9 \%$ & Baik \\
\hline
\end{tabular}

c. Nilai rata-rata kelas untuk tes evaluasi pada siklus II adalah 85,7. untuk data prestasi belajar siswa pada siklus II ini bisa dilihat pada Tabel 4 berikut ini:

Tabel 4. Data Prestasi Belajar Siswa Siklus II

\begin{tabular}{cccc}
\hline $\begin{array}{c}\text { Jumlah } \\
\text { siswa }\end{array}$ & $\begin{array}{c}\text { Jumlah } \\
\text { siswa } \\
\text { yang }\end{array}$ & $\begin{array}{c}\text { Persentase } \\
\text { ketuntasan }\end{array}$ & $\begin{array}{c}\text { Rata- } \\
\text { rata hasil }\end{array}$ \\
\hline
\end{tabular}

\begin{tabular}{cccc}
\hline $\begin{array}{c}\text { tuntas } \\
\text { belajar }\end{array}$ & $\begin{array}{c}\text { tidak } \\
\text { tuntas } \\
\text { belajar }\end{array}$ & & $\begin{array}{c}\text { tes } \\
\text { formatif }\end{array}$ \\
\hline 31 & 5 & $86,1 \%$ & 85,7 \\
\hline
\end{tabular}

\section{Pembahasan}

Keterlaksanaan proses pembelajaran problem posing dalam upaya meningkatkan kemampuan komunikasi dan pretasi belajar siswa kelas X-A salah satu MAN Kota Malang mengalami peningkatan antara siklus I dan siklus II. Pada siklus I persentase keterlaksanaan pembelajaran problem posing sebesar $80 \%$ dan mengalami peningkatan pada siklus II menjadi sebesar $90 \%$. Rerata keterlaksanaan pendekatan problem posing pada siklus pertama dan kedua untuk indikator-indikator tertentu mengalami peningkatan. Peningkatan ini terjadi setelah diberikan tindakan dalam langkah-langkah pendekatan problem posing. Kemampuan komunikasi yang dimaksud adalah kemampuan menyampaikan pikiran dan perasaan, kemampuan memahami orang lain, kemampuan memberikan dukungan serta kemampuan mengungkapkan diri pada orang lain (Sinambela 2013). Hasil dari kemampuan komunikasi siswa dalam diskusi disajikan pada Tabel 5 berikut ini.

Tabel 5. Hasil Kemampuan Komunikasi Siswa

\begin{tabular}{cc}
\hline Siklus & Rata-rata \\
\hline Siklus I & $67,6 \%$ \\
Siklus II & $75 \%$ \\
\hline
\end{tabular}

Pada siklus II rata-rata kemampuan komunikasi lebih baik dari siklus I. Hal ini menunjukkan bahwa dengan penerapan pendekatan problem posing dapat meningkatkan kemampuan komunikasi siswa kelas X-A salah satu MAN di Kota Malang. Untuk hasil persentase pada setiap aspek kemampuan komunikasi siswa antara siklus I dan II dapat dilihat pada Tabel 6 berikut ini. 
Tabel 6. Persentase Kemampuan Komunikasi Siswa Kelas X-A MAN 3 Malang untuk Setiap Aspeknya.

\begin{tabular}{|c|c|c|c|c|}
\hline \multirow{2}{*}{$\begin{array}{c}\text { Aspek } \\
\text { yang } \\
\text { Diukur }\end{array}$} & \multicolumn{2}{|c|}{$\begin{array}{c}\text { Persentase } \\
\text { (jumlah) }\end{array}$} & \multirow{2}{*}{$\begin{array}{l}\text { Seli } \\
\text { sih } \\
(\%)\end{array}$} & \multirow[t]{2}{*}{$\begin{array}{c}\text { Keteranga } \\
\text { n }\end{array}$} \\
\hline & $\begin{array}{c}\text { Siklus } \\
\text { I }\end{array}$ & $\begin{array}{c}\text { Siklus } \\
\text { II }\end{array}$ & & \\
\hline $\begin{array}{l}\text { Kemampuan } \\
\text { menyampai } \\
\text { kan pikiran } \\
\text { dan } \\
\text { perasaan }\end{array}$ & $78,7 \%$ & $75,9 \%$ & 2,8 & Menurun \\
\hline $\begin{array}{l}\text { Kemampuan } \\
\text { memahami } \\
\text { orang lain }\end{array}$ & $66,7 \%$ & $78,7 \%$ & 12 & Meningkat \\
\hline $\begin{array}{l}\text { Kemampuan } \\
\text { memberi } \\
\text { dukungan }\end{array}$ & $46,3 \%$ & $69,4 \%$ & 23,1 & Meningkat \\
\hline $\begin{array}{l}\text { Kemampuan } \\
\text { mengungka } \\
\text { pkan diri }\end{array}$ & $78,7 \%$ & $75,9 \%$ & 2,8 & Menurun \\
\hline
\end{tabular}

Pembentukan soal pada tahapan problem posing selain dapat mempermudah siswa dalam memahami materi, juga akan melatih siswa untuk bisa saling berbagi informasi dan mengemukakan jawaban dalam kelompoknya. Dengan demikian siswa akan lebih aktif dalam proses pembelajaran. Hal ini sesuai dengan pendapat Suparno, dkk (Syarifudin 2012), yang mengemukakan bahwa siswa yang aktif dalam proses pembelajaran memiliki beberapa kemampuan dasar. Pertama, kemampuan bertanya yaitu kemampuan siswa untuk mengajukan masalah yang diwujudkan dalam bentuk pertanyaan. Kedua, kemampuan memecahkan masalah. Permasalahan yang muncul dalam pembelajaran harus diselesaikan oleh siswa selama proses belajarnya. Ketiga, kemampuan berkomunikasi yang merupakan sarana agar terjadi pemahaman yang benar. Berikut ini data prestasi belajar siswa

Tabel 7. Data Prestasi Belajar Siswa

\begin{tabular}{ccc}
\hline Siklus & $\begin{array}{c}\text { Jumlah siswa } \\
\text { yang tuntas } \\
\text { belajar }\end{array}$ & $\begin{array}{c}\text { Jumlah siswa yang } \\
\text { tidak tuntas belajar }\end{array}$ \\
\hline I & 13 & 23 \\
II & 31 & 5 \\
\hline
\end{tabular}

Berdasarkan Tabel 7 dapat diketahui bahwa nilai rata-rata kelas pada siklus I hanya 69,7. Hal ini dikarenakan pada siklus I proses pembelajaran dengan model problem posing ini belum maksimal dilakukan, yang akhirnya berdampak pada nilai hasil tes formatif siswa. Pada siklus I, dalam tahap mendeskripsikan situasi/informasi, guru hanya meberikan penjelasan awal mengenai konsep materi gelombang elektromagnetik tanpa disertai demonstrasi maupun praktikum. Jadi pemikiran siswa hanya berupa teori saja tanpa ada praktek secara langsung.

Pada siklus I ini, siswa masih merasa asing dengan model pembelajaran yang dilakukan, sehingga siswa belum terbiasa untuk belajar dengan model pembelajaran problem posing. Sementara pada siklus II, proses keterlaksanaan model pembelajaran problem posing ini sudah hamper mendekati sempurna. Dan siswa juga sudah mengerti dan terbiasa belajar dengan model problem posing ini. Selain itu pada akhir pembelajaran pada siklus I, guru sudah memberi tahu siswa bahwa untuk pertemuan selanjutnya tetap menggunakan model problem posing, jadi siswa diminta untuk mempersiapkan diri mempelajari materi selanjutnya.

Proses pembelajaran problem posing dapat meningkatkan kemampuan komunikasi siswa kelas X-A salah satu MAN Kota Malang. Penerapan pendekatan problem posing ini yang lebih menekankan pada saat siswa membuat suatu permasalahan kemudian permaslahan tersebut dipecahkan secara bersama-sama atau dengan diskusi. Siswa dituntut untuk saling berbagi informasi antara siswa yang satu dengan siswa dalam satu kelompoknya maupun dengan seluruh siswa di kelas. Jadi penerapan pendekatan problem posing dapat meningkatkan kemampuan komunikasi siswa. Rata-rata nilai kemampuan kBensentassi siswa paRastakhasd adalah 67,6\% dan ketuphtdsagiklasilkalmengdhasil teseningkatan menjadi 75\%. Jadi disini dapaffermatifbahwa kemampuan koßrunikeasi siswa naengalami peningkatan sebsesar\%, $4 \%$. $\quad 85,7$ 
Berdasarkan Tabel 7 dapat diketahui bahwa nilai rata-rata kelas pada siklus II mengalami peningkatan bila dibandingkan dengan siklus I. Berdasarkan ketuntasan klasikal dan rata-rata kelas menunjukkan bahwa tejadi peningkatan kemampuan kognitif siswa antara siklus I dan siklus II. Hal ini dapat dikatakan bahwa proses pembelajaran dengan model problem posing ini dapat meningkatkan penguasaan materi pada siswa sehingga prestasi belajarnya pun mengalami peningkatan.

Hasil penelitian ini menunjukkan bahwa berbagai macam metode dan pendekatan yang digunakan dalam pembelajaran merupakan salah satu cara meningkatkan kualitas pendidikan. Pendekatan pembelajaran yang banyak dikembangkan adalah pembelajaran berbasis konstruktivisme (Trianto 2007). Pembelajaran konstruktivisme ini berorientasi pada aktivitas dan keterlibatan siswa secara aktif dalam memahami materi pembelajaran. Pergeseran paradigma pembelajaran yang sebelumnya lebih menitikberatkan pada peran guru demikian besar bergeser pada pemberdayaan peserta didik atau siswa dalam mengambil inisiatif dan partisipasi di dalam kegiatan belajar.

Konstruktivisme dalam penelitian ini mampu mengembangkan pembelajaran dengan berbasis kepada pemahaman siswa. Jika ingin memahami apa yang telah di ketahui siswa dan dapat memonitor perkembangan prestasi pembelajaran dan pengetahuan siswa maka faktor pemahaman siswa harus menjadi perhatian guru. Tugas guru adalah memahami faktor-faktor intrinsik yang ada dalam diri siswa. Dengan demikian, menciptakan situasi pembelajaran yang menarik dan kondusif, bukan semata tugas guru. Guru harus bisa menciptakan alat reinforcement yang bagus. Sebaliknya, dalam paradigma konstruktivistik, siswa juga memiliki potensi intrinsik dalam menciptakan lingkungan belajar yang kondusif (Trianto 2007).

Salah satu bentuk pembelajaran berbasis konstruktivisme adalah pembelajaran dengan pendekatan Problem Posing (Joyce, Weil, and Calhoun 2009). Problem posing dilakukan siswa dengan cara merumuskan atau membentuk soal dari suatu situasi yang sudah tersedia. Merumuskan soal merupakan suatu aktivitas dalam pembelajaran yang dapat mengembangkan motivasi dan kemampuan siswa. Dalam pembelajaran dengan menggunakan pendekatan problem posing, siswa dapat memperoleh pengetahuan secara langsung dalam merumuskan soalnya sendiri (Azhar 2001).

Hasil penelitian para ahli pendidikan menemukan bahwa pembelajaran dengan problem posing lebih berdampak positif terhadap hasil belajar siswa. Menurut penelitian Azhar (Azhar 2001) dikatakan bahwa pendekatan problem possing lebih efektif dalam meningkatkan prestasi belajar siswa daripada pembelajaran konvensional. Pembelajaran konvensional yang dimaksud adalah proses pembelajaran yang lebih banyak didominasi oleh guru sebagai pentransfer ilmu, sementara siswa lebih pasif sebagai penerima ilmu.

Jadi dengan adanya proses diskusi ini diharapkan dapat meningkatkan kemampuan komunikasi siswa. Adanya penerapan pendekatan problem posing diharapkan kecakapan komunikasi dapat meningkat. Implementasi pendekatan problem posing siswa menjadi terbiasa untuk dapat mengemukakan jawaban atau permasalahan yang mereka hadapi walaupun masih dalam kelompok, sehingga mereka terbiasa dan mau mengemukakan pendapat atau permasalahan dalam pembelajaran.

\section{KESIMPULAN}

Rendahnya kemampuan nalar, inovasi dan komunikasi di salah satu sekolah di Malang memicu dilakukannya penelitian secara langsung atau observasi langsung dengan empat tahapan penelitian tindakan kelas yang diantaranya adalah perencanaan, tindakan, observasi, dan refleksi. Penelitian ini dilakukan agar kemampuan siswa yang masih rendah dalam ketiga hal tersebut dapat meningkat. Selain itu, pembelajaran satu arah yang 
masih berpusat pada guru perlu diubah ke arah pemusatan belajar kepada siswa. Dalam penelitian ini, penerapan proses pembelajaran problem posing mampu meningkatkan prestasi belajar siswa kelas $\mathrm{X}-\mathrm{A}$ salah satu MAN Kota Malang. Pada proses pembelajaran ini siswa dilibatkan secara aktif. Selain itu, efek lain dari penerapan problem posing adalah kemampuan komunikasi siswa meningkat. Tahapan dalam problem posing mampu melibatkan siswa secara nyata untuk berfikir kritis, kreatif, komunikatif, dan problem solving. Karena itu, perlu dikembangkan lebih lanjut untuk melakukan penelitian sejenis. Namun, peneliti berikut hendaknya mengkolaborasikan model pembelajaran problem posing dengan model pembelajaran sehingga memberi peluang kepada siswa mengembangkan kemampuan-kemampuan yang lain.

\section{DAFTAR PUSTAKA}

Alshamali, Mahmoud A. and Wajeeh M. Daher. 2016. "Scientific Reasoning and Its Relationship with Problem Solving: The Case of Upper Primary Science Teachers." International Journal of Science and Mathematics Education 14(6):1003-19.

Azhar, Azhar. 2001. Keefektifan Metode Problem Posing Dan Deskripsi Kemampuan Problem Posing Siswa Pada Pembelajaran Stoikinometri (Suatu Penelitian Di Zona Industri Aceh Timur). Malang: Universitas Negeri Malang: Tesis Tidak Dipublish.

Barak, Miri. 2017. "Science Teacher Education in the Twenty-First Century: A Pedagogical Framework for Technology-Integrated Social Constructivism." Research in Science Education 47(2):283-303.

Bollen, Laurens, Paul Van Kampen, Charles Baily, Mieke De Cock, K. U. Leuven, Departemen Fisika, I. Pendahuluan, and Laurens Bollen. 2016. "Penyelidikan Kualitatif Menjadi Siswa ' Penggunaan Divergensi Dan Keriting Di Elektromagnetisme II . THE KONSEPTUAL BLENDING KERANGKA.” 134:1-14.
Care, Esther, Patrick Griffin, and Mark Wilson. 2018. Assessment and Teaching of 21st Century Skills. Springer International Publishing AG.

Creswell, John W. 2009. RESEARCH DESIGN: Qualitative, Quantitative, and Mixed Methods Approaches. 3rd Ed. United States of America: New York: SAGE Publications, Inc.

Enden, Suhila, Rochman Chaerul, and Endah Kurnia Yuningsih. 2016. "Penerapan Model Pembelajaran Scientific Inquiry Untuk Meningkatkan Kemampuan Literasi Sains Peserta Didik Pada Sub Materi Pokok Fluida Dinamis." Journal of Teaching and Learning Physics 1(1):7-12.

Feinstein, Noah Weeth and Kathryn L. Kirchgasler. 2015. "Sustainability in Science Education? How the Next Generation Science Standards Approach Sustainability, 